BMJ Paediatrics Open

\section{Fast I(n)dentification of Pathogens in Neonates (FINDPATH-N): protocol for a prospective pilot cohort study of next- generation sequencing for pathogen identification in neonates with suspected sepsis}

To cite: Klowak JA, el Helou S, Pernica JM, et al. Fast I(n) dentification of Pathogens in Neonates (FINDPATH-N): protocol for a prospective pilot cohort study of nextgeneration sequencing for pathogen identification in neonates with suspected sepsis. BMJ Paediatrics Open 2020;4:e000651. doi:10.1136/ bmjpo-2020-000651

- Additional material is published online only. To view, please visit the journal online (http://dx.doi.org/10.1136/ bmjpo-2020-000651).

Received 29 January 2020 Revised 19 March 2020 Accepted 20 March 2020

Check for updates

(c) Author(s) (or their employer(s)) 2020. Re-use permitted under CC BY-NC. No commercial re-use. See rights and permissions. Published by BMJ.

For numbered affiliations see end of article.

Correspondence to Dr Alison E Fox-Robichaud; afoxrob@mcmaster.ca

\section{ABSTRACT}

Introduction Sepsis is a major source of morbidity and mortality in neonates; however, identification of the causative pathogens is challenging. Many neonates have negative blood cultures despite clinical evidence of sepsis. Next-generation sequencing (NGS) is a high-throughput, parallel sequencing technique for DNA. Pathogen-targeted enrichment followed by NGS has the potential to be more sensitive and faster than current gold-standard blood culture. In this pilot study, we will test the feasibility and pathogen detection patterns of pathogen-targeted NGS in neonates with suspected sepsis. Additionally, the distribution and diagnostic accuracy of biomarkers cellfree DNA and protein $\mathrm{C}$ levels at two time points will be explored.

Methods and analysis We will conduct a prospective, pilot observational study. Neonates over $1 \mathrm{~kg}$ with suspected sepsis from a single tertiary care children's hospital will be recruited for the study. Recruitment will be censored at 200 events or 6 months' duration. Two blood study samples will be taken: the first simultaneous to the blood culture (time $=0$ hour, for NGS and biomarkers) via an exception to consent (deferred consent) and another 24 hours later after prospective consent (biomarkers only). Neonates will be adjudicated into those with clinical sepsis, culture-proven sepsis and without sepsis based on clinical criteria. Feasibility parameters (eg, recruitment) and NGS process time will be reported.

For analysis, NGS results will be described in aggregate, compared with the simultaneous blood culture (sensitivity and specificity) and reviewed via expert panel for plausibility. Pilot data for biomarker distribution and diagnostic accuracy (sensitivity and specificity) for distinguishing between septic and non-septic neonates will be reported.

Ethics and dissemination Ethics approval has been granted by the Hamilton Integrated Research Ethics Board. We will seek publication of study results in peer-reviewed journals.

\section{What is already known on this topic?}

Sepsis is a major source of morbidity and mortality in neonates.

- There is no true gold standard for the definition of neonatal sepsis.

- Targeted next-generation sequencing (NGS) is a high-throughput sequencing technique with the potential to be more sensitive and faster than blood culture.

\section{What this study hopes to add?}

- This pilot observational study explores the need for a faster, more sensitive and specific test for neonatal sepsis using novel methodology.

- The primary objective was to determine the feasibility of a trial of targeted NGS of DNA to identify blood pathogens in neonates with suspected sepsis.

\section{INTRODUCTION}

Sepsis is a major source of mortality and morbidity in neonates; however, there is no consensus definition or standard for neonatal sepsis. ${ }^{12}$ Blood culture sensitivity can be limited in cases of low blood volume (eg, under $1 \mathrm{~mL}$ ) or prior administration of antibiotics. ${ }^{3}$ Biomarkers for neonatal sepsis have been studied extensively, but so far, there is no single adequately rapid and accurate biomarker or scoring system. ${ }^{4}$ Procalcitonin-guided treatment reduces antibiotic duration in early onset neonatal sepsis but requires serial measurements. ${ }^{5}$ Due to the lack of a rapid and accurate diagnostic test, neonates are at risk of overtreatment with 
antimicrobials and their associated toxicities or inadequate antimicrobial treatment. These factors create an ongoing need for a rapid and sensitive diagnostic test for neonatal sepsis.

\section{Next-generation sequencing}

Next-generation sequencing (NGS) is a high-throughput, parallel sequencing technique for DNA and RNA that has correctly identified pathogens in septic adults. ${ }^{67}$ The theoretic clinical benefits of NGS include reduced blood volume $(<0.5 \mathrm{~mL})$, increased speed compared with standard blood culture and fast antibiotic resistance gene identification, aiding in diagnostic clarity and decisions around antibiotic type and duration. ${ }^{78}$ Total laboratory process time is under 24 hours, but time with real-life conditions has yet to be assessed. ${ }^{9}$ Since detection is not based on growth, detection may be possible even after antibiotic administration, and identification of polymicrobial infections may be improved. NGS can identify viral, bacterial and fungal DNA in one test, unlike blood culture. Two small studies have shown increased sensitivity of NGS relative to blood culture for pathogen identification in septic adults. ${ }^{79}$ Gosiewski et al detected bacterial DNA using NGS in 23 healthy volunteers. ${ }^{10}$ The taxonomy of the bacteria, predominately intestinal microbiota in healthy volunteers, is significantly different in septic patients. These findings indicate that NGS requires stringent controls and interpretation.

Multiplex PCR has also been studied for rapid pathogen detection in sepsis. However, limitations exist, including a lack of quantitative output for some PCR methods, variable sensitivity and a restricted range of pathogen recognition, with variable study quality. ${ }^{11} 12$ NGS offers the advantage of semiquantitative output and a larger range of pathogen recognition over PCR-based methods.

\section{Novel pathogen-targeted NGS system}

We have designed novel biotin-labelled pieces of RNA termed baits. The baits are around 80 base pairs (bp) long and map to unique regions ('Kmers') on a wide variety of fungal, viral and bacterial species in a hierarchical fashion. Pathogen DNA is enriched through hybridisation with the baits, which are pulled out of solution using streptavidin-coated magnetic beads. ${ }^{13}$

\section{Biomarkers in neonatal sepsis}

Numerous biomarkers such as $\mathrm{C}$ reactive protein and procalcitonin have been studied extensively in neonatal sepsis. ${ }^{41415}$ However, there is not yet a biomarker with the high diagnostic accuracy and short turnaround time desired for clinical decisions around antibiotic therapy and hospital admission.

\section{Cell-free DNA (cfDNA) and protein C}

cfDNA is freely circulating DNA and can be found in blood plasma. Levels of cfDNA have shown prognostic utility in adult trauma, ${ }^{16}$ cancer $^{17}$ and sepsis. ${ }^{18-20}$ In a case-control study of 27 very preterm infants, the level of cfDNA was elevated at late-onset sepsis diagnosis and trended higher even days prior to the onset of necrotising enterocolitis. $^{21}$

Protein $\mathrm{C}$ is a glycoprotein with anticoagulant activity through regulation of thrombin activity. Protein $\mathrm{C}$ has been studied as a potential treatment for severe neonatal sepsis using activated protein $\mathrm{C}$ concentrate, although there is no clear evidence of benefit. ${ }^{22}$ Protein $\mathrm{C}$ levels are significantly higher in healthy controls compared with septic neonates, and protein $\mathrm{C}$ has been described as a useful biomarker in severe sepsis. ${ }^{23}$ Protein $\mathrm{C}$ has also demonstrated prognostic utility for mortality in septic low birthweight neonates. ${ }^{24}$ There is a paucity of research on the diagnostic capability of protein $\mathrm{C}$ levels to identify neonatal sepsis.

\section{Rationale}

Both NGS and the biomarkers cfDNA and protein $\mathrm{C}$ have the potential to improve care for neonates with sepsis through rapid and sensitive identification of pathogens and improved diagnostic accuracy, respectively. In this pilot study, we will test the feasibility and pathogen detection patterns of NGS in neonates with suspected sepsis. Additionally, cfDNA and protein $\mathrm{C}$ levels at two time points will be analysed for diagnostic capability of clinical and culture-proven sepsis.

\section{Objectives}

The objectives of this study are shown in table 1 .

\section{METHODS}

\section{Design of study}

Fast I(n)dentification of Pathogens in Neonates (FINDPATH-N) is a prospective, observational single-centre cohort study in Hamilton, Ontario, Canada. The study design is shown in figure 1 .

\section{Study setting}

Potential patients will be from levels 2 and 3 neonatal intensive care units (NICUs) in a paediatric tertiary care hospital (McMaster Children's Hospital) in Hamilton, Ontario, Canada.

\section{Eligibility criteria} Inclusion criteria

1. Patient in level 2 or level 3 NICU with physician or nurse practitioner order to draw blood culture.

2. Current or birth weight over $1 \mathrm{~kg}$.

\section{Exclusion criteria}

1. Substitute decision maker (SDM) has previously declined consent for FINDPATH-N.

2. Patient apprehended by Children's Aid Society.

3. SDM is a known Jehovah's witness.

\section{Study processes}

Patient recruitment and first sample

Study education sessions and posters will increase awareness and inform staff about study processes. For the 
Table 1 Objectives, outcome measures and methods of analysis for Fast I(n)dentification of Pathogens in Neonates pilot study

\begin{tabular}{|c|c|c|}
\hline Objective & Outcome measure & Method of analysis \\
\hline \multicolumn{3}{|l|}{ Co-primary objectives } \\
\hline 1. Recruitment. & $\begin{array}{l}\text { Successful recruitment is defined as } \geq 80 \% \text { of } \\
\text { eligible patients. }\end{array}$ & Proportion \\
\hline 2. Sample collection. & $\begin{array}{l}\text { Successful sample collection is defined as } \\
\geq 80 \% \text { of the blood samples for recruited } \\
\text { patients at the first time point. }\end{array}$ & Proportion \\
\hline $\begin{array}{l}\text { 3. Ability to perform NGS on blood samples of } \\
\text { premature and term neonates at MCH with suspected } \\
\text { sepsis. }\end{array}$ & Description of mechanical or process issues & Descriptive only \\
\hline \multicolumn{3}{|l|}{ Secondary objectives } \\
\hline $\begin{array}{l}\text { 1. To describe the blood NGS pathogen output in } \\
\text { order to gain a preliminary understanding of the } \\
\text { potential clinical role of NGS testing in neonates with } \\
\text { suspected sepsis. }\end{array}$ & $\begin{array}{l}\text { NGS pathogen output (taxonomy, reads, } \\
\text { plausibility from panel review) }\end{array}$ & $\begin{array}{l}\text { Descriptive statistics } \pm \text { case } \\
\text { discussions }\end{array}$ \\
\hline $\begin{array}{l}\text { 2. To describe the serum levels and diagnostic } \\
\text { accuracy of biomarkers cfDNA and protein } C \text { at time } \\
\text { points of } 0 \text { and } 24 \text { hours between neonates with } \\
\text { clinical sepsis, culture-proven sepsis and without } \\
\text { sepsis. }\end{array}$ & $\begin{array}{l}\text { Levels of blood cfDNA and protein C, sensitivity } \\
\text { and specificity (\%), likelihood ratios }\end{array}$ & $\begin{array}{l}\text { Descriptive statistics, diagnostic } \\
\text { accuracy measures with } \mathrm{Cls}\end{array}$ \\
\hline $\begin{array}{l}\text { 3. To compare the sensitivity and specificity of NGS } \\
\text { for bacterial identification compared with gold- } \\
\text { standard aerobic blood culture. }\end{array}$ & Sensitivity and specificity (\%) & Proportion and Cls \\
\hline $\begin{array}{l}\text { 4. To determine blood sample NGS laboratory } \\
\text { process time. }\end{array}$ & $\begin{array}{l}\text { Process time from thawing sample to sequence } \\
\text { acquisition (hours) }\end{array}$ & Descriptive only \\
\hline $\begin{array}{l}\text { 5. To determine consent rate using an exception to } \\
\text { consent (deferred consent). }\end{array}$ & $\begin{array}{l}\text { The target consent rate is } \geq 80 \% \text { of families } \\
\text { approached }\end{array}$ & Proportion \\
\hline
\end{tabular}

cfDNA, cell-free DNA; Cl, confidence interval; $\mathrm{MCH}$, McMaster Children's Hospital; NGS, next-generation sequencing.

6-month study period, a blood culture being ordered will act as a cue for nursing staff to check eligibility. Chart inserts and stickers will be used to identify patient consent status. If eligible, $650 \mu \mathrm{L}$ of blood will be collected via deferred consent in two separate study tubes (one $350 \mu \mathrm{L}$ EDTA tube for NGS and one $300 \mu \mathrm{L}$ EDTA tube for biomarkers) at the same time as the blood culture, which has a set minimum volume of $0.5 \mathrm{~mL}$. The order of priority is clinical samples first.

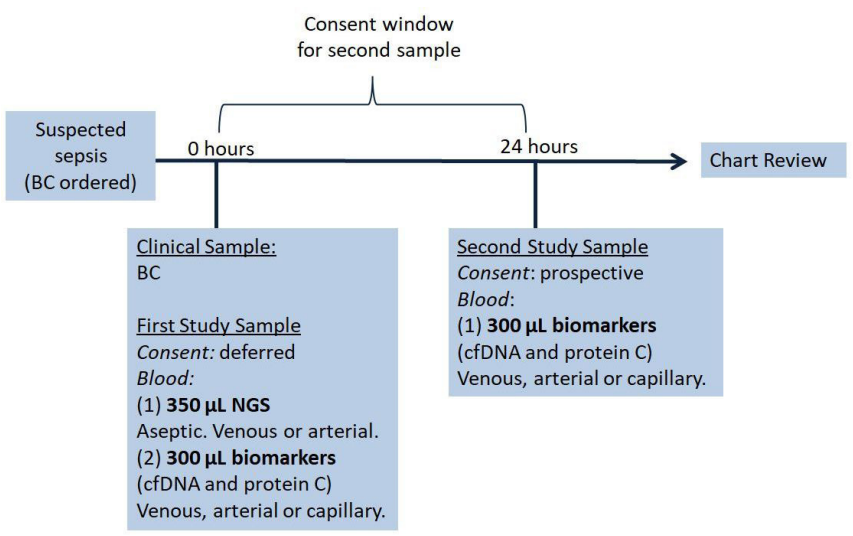

Figure 1 FINDPATH-N studyworkflow. Abbreviations: BC (bloodculture), NGS (next generation sequencing), cfDNA (cell-free DNA).
Consenting and second sample

Study personnel will approach SDMs for consent in person or via telephone within 24 hours of the first blood sample. Before approaching the family, the study personnel will make a reasonable effort to ensure that a medical update has been given and obtain permission to approach via a member of the circle of care. If consent is obtained for a second sample $(300 \mu \mathrm{L}$ EDTA tube for biomarker analysis), study personnel will write a 'suggest order' in the chart for this to be drawn $24 \pm 4$ hours from the time of the first sample. If the SDM is not able to be reached within 24 hours, the second sample will not be collected. Later attempts to contact the SDM will be made so that the first sample may still be used. If consent is not obtained for inclusion in the study, the blood sample collected via an exception to consent will be destroyed. Study personnel will maintain a master list to log consent and sample acquisition throughout the study period. Automated online searches for use of the study code by nursing staff will serve as a backup to notification from the clinical team.

\section{Sample size calculation}

We will censor the study at 200 events of suspected sepsis or 6 months' duration. In general, pilot studies do not require sample size calculations. ${ }^{25}$ The 200 events will allow a CI estimate of the primary feasibility outcomes 
with a margin of error less than 0.1 when expected rates are $0.8 .{ }^{25}$ Results from this study could serve to inform the sample size of a larger trial.

\section{Patient data collection methods}

We have developed a detailed case report form. Trained data abstractors will review the charts of participants and record patient demographic data, timing of blood culture and sample collection, treatment details, vital signs, laboratory data and clinical outcomes data.

\section{Definitions and adjudication}

Patients will be adjudicated into those with and without sepsis (subclassifications: culture-proven and clinical; see online supplementary definitions 1) using definitions adapted from previous literature. ${ }^{26}{ }^{27}$ There is currently no consensus definition for neonatal sepsis. ${ }^{2}$ All NGSpositive results will be reviewed for plausibility by a panel, which will include a neonatologist, a paediatrician and a paediatric infectious disease specialist, and will use majority voting.

\section{Data management}

Data with personal identifiers will be stored on an encrypted USB in a locked drawer in a locked institution. Data will be deidentified using a study code. REDCap, a secure web application, will be used to build and manage our study database. ${ }^{28}$ Range checks will be performed for all continuous data. Data will be destroyed after 10 years.

\section{Monitoring}

A data safety and monitoring committee was deemed unnecessary due to the short study duration and this being an observational, minimal-risk study. The primary investigator will monitor recruitment, consent processes and sample collection on a weekly basis.

\section{Laboratory protocols for index tests Storage}

Samples for NGS will be frozen as whole blood at $-20^{\circ} \mathrm{C}$. Biomarker samples will be frozen as plasma at $-80^{\circ} \mathrm{C}$. Any remaining blood will be stored for up to 10 years for future pathogen and biomarker analysis.

\section{Biomarker analysis}

Levels of cfDNA and protein $\mathrm{C}$ will be quantified from plasma via a Qiagen cfDNA extraction kit, as previously described, ${ }^{18}$ and an ELISA, respectively.

\section{NGS library preparation}

Total DNA is placed into double-stranded and singlestranded DNA libraries using methodology designed at McMaster University (H Poinar, personal communication 2019) and modified from previous work. ${ }^{29}$ DNA libraries are then barcoded using indexed primers for each individual blood sample. These indexed libraries are then subjected to targeted enrichment.

\section{Pathogen-targeted enrichment}

We will use biotin-labelled RNA baits ( $80 \mathrm{bp}$ ) corresponding to unique regions in bacterial, fungal and viral species genomes. The baits are manufactured using myBaits (Arbour Biosciences, Michigan, USA). The large list of pathogens was created via consensus decision with infectious disease specialist input. Indexed library samples will undergo hybridisation with the pathogen baits for between 2 and 12 hours (final sensitivity testing pending) at $55^{\circ} \mathrm{C}-65^{\circ} \mathrm{C}$ followed by magnetic purification using streptavidin-coated magnetic beads to enrich the level of pathogen versus human DNA in the sample. ${ }^{30}$

\section{Sequencing}

Enriched samples will undergo NGS using an Illumina HiSeq 1500flx sequencing platform in the Farncombe Family Digestive Health Research Institute, McMaster University. ${ }^{6}{ }^{31}$ We will use three biological replicates per sample group where possible, with a minimum of two technical repetitions. Sequences will be analysed using a proprietary pipeline that trims, merges and collapses sequences for final comparison using metagenomic analysis software. Analysis software includes DUDes, Kraken2, DIAMOND, MegaBlast and direct mapping using Burrows-Wheeler Alignment. ${ }^{33}$ Healthy adult blood samples will serve as negative controls, and blood samples spiked with multiple bacterial strains with variable genome size and guanine or cytosine content will serve as positive controls. Future research may explore whether healthy neonatal controls have differing levels of pathogen DNA than adult healthy controls.

\section{Quality controls}

Any thick, red plasma samples will be excluded due to likely hemolysis. The purity of cfDNA isolate will be assessed and reported using an absorbance $(260 \mathrm{~nm} / 280 \mathrm{~nm})$ ratio via spectrophotometer. The protein C ELISA will have duplicate samples where possible and concentration standards.

For every five sequencing reactions, we will include an extraction, an indexing, a library preparation and an enrichment control. All sequences found within the controls are used as a decontamination database to assess potential contamination in our clean room facilities.

\section{ANALYSIS}

\section{Co-primary outcomes}

Co-primary outcomes are described in table 1 .

\section{Secondary outcomes}

NGS pathogen output

Types of bacteria, fungi and viruses identified will be described using both species-level terminology and higherlevel taxonomy. Taxonomy patterns will be compared in relation to the adjudicated clinical subgroups (cultureproven sepsis, clinical sepsis and no sepsis) with descriptive statistics. Plausibility of NGS results by panel review 
will be reported using descriptive statistics. Individual case data have the potential to suggest increased sensitivity of NGS if a blood culture-negative patient is NGSpositive for a corresponding pathogen found in a culture of the patient's cerebrospinal fluid or urine. Quantitative or semiquantitative NGS output will be reported with descriptive statistics.

\section{cfDNA and protein $\mathrm{C}$ distribution and diagnostic accuracy}

Levels of cfDNA and protein $\mathrm{C}$ at 0 and 24 hours will be described with descriptive statistics by clinical groups. Levels of cfDNA and protein $\mathrm{C}$ at 0 and 24 hours will be assessed for ability to discriminate between patients who have clinical or culture-proven sepsis and those who do not. Sensitivity and specificity will be reported for multiple potential cut-off values. If there are adequate data available, receiver operator curves will be created. Likelihood ratios will also be reported.

\section{Sensitivity and specificity of NGS versus gold-standard aerobic blood culture}

The number of species-corresponding NGS-positive and blood culture-positive samples will be divided by the total number of blood culture-positive samples to calculate the sensitivity. The sensitivity and specificity of NGS vs blood culture will be reported as a per cent with an associated $95 \%$ CI.

\section{NGS laboratory process time}

The process time from thawing the sample to sequence acquisition will be recorded in hours.

\section{Consent rate using initial exception to consent (deferred consent)}

Our target consent rate is $\geq 80 \%$ of families approached for consent.

\section{Patient and public involvement}

There was no patient or public involvement in this study creation.

\section{ETHICS AND DISSEMINATION Ethics approval}

This study was approved by the Hamilton Integrated Research Ethics Board (HiREB) on 2 August 2019 (project \#5869). Any modifications to the study protocol will be communicated to HiREB.

\section{Consent and recruitment}

An exception to consent (deferred consent) will be used for the first biological specimen because prospective consent is not feasible; sample acquisition poses very minimal harm; and research on neonatal sepsis has significant potential future benefit. Prospective consent is not feasible because the NGS sample must be simultaneous to the current gold-standard blood culture, which is typically acquired in a timely fashion prior to antibiotic administration. Administration of antibiotics in suspected sepsis should be within 1 hour. ${ }^{34}$ Additionally, in a prospective consent model, SDMs would likely be under emotional stress and not able to optimally listen to the study team members for urgent informed consent.

This study poses very minimal harm to the neonate. Exception to consent is for a single-study sample of $650 \mu \mathrm{L}$ or $0.65 \mathrm{~mL}$. Our smallest study participant would be $1 \mathrm{~kg}$, making this less than 1 per cent of our smallest study participant's estimated total blood volume. When using an exception to consent, there will be no additional venous pokes for the study.

\section{Dissemination}

We will seek publication in a peer-reviewed journal and presentation at conferences and share these data within the Canadian Critical Care Translational Biology Group.

\section{Current status of the study}

Recruitment started on 15 October 2019 and will be complete by 14 April 2020. As of 24 January 2019, 24 events have been enrolled.

Author affiliations

${ }^{1}$ Pediatrics, McMaster University, Hamilton, Ontario, Canada

${ }^{2}$ Pediatrics, McMaster Children's Hospital, Hamilton, Ontario, Canada

${ }^{3}$ Medicine, McMaster University, Hamilton, Ontario, Canada

${ }^{4}$ Anthropology, McMaster University, Hamilton, Ontario, Canada

${ }^{5}$ Thrombosis and Atherosclerosis Research Institute, Hamilton, Ontario, Canada

Twitter Jennifer Ann Klowak @JenniferKlowak

Collaborators We thank Drs. Patricia Liaw, Jamie Hutchinson, Jane Batt, Emmanuel Charbonney, Christopher Ellis and Jean-François Cailhier for their support and for many helpful discussions as part of the Canadian Critical Care Translational Biology Group.

Contributors All authors were involved in the design of the study. JAK, SeH and JMP designed the study definitions. JAK and AF-R drafted the manuscript, which all the other authors reviewed and approved.

Funding This work was supported by a McMaster University Paediatric Resident Research Award (Hamilton, Ontario, Canada). JAK was supported by a Canadian Institutes of Health Research (CIHR) Canada Graduate Scholarship-Master's. AF- $\mathrm{R}$ is supported by a Collaborative Health Research Programme (CIHR/Natural Sciences and Engineering Research Council 146477) grant to develop a pointof-care cfDNA device. HP is supported by funding from the Boris Family. MJP is supported by a Canadian Blood Services/CIHR New Investigator Award.

Competing interests None declared.

Patient and public involvement Patients and/or the public were not involved in the design, or conduct, or reporting, or dissemination plans of this research.

Patient consent for publication Not required.

Provenance and peer review Not commissioned; externally peer reviewed.

Open access This is an open access article distributed in accordance with the Creative Commons Attribution Non Commercial (CC BY-NC 4.0) license, which permits others to distribute, remix, adapt, build upon this work non-commercially, and license their derivative works on different terms, provided the original work is properly cited, appropriate credit is given, any changes made indicated, and the use is non-commercial. See: http://creativecommons.org/licenses/by-nc/4.0/.

ORCID iDs

Jennifer Ann Klowak http://orcid.org/0000-0001-9917-8789

Jeffrey M Pernica http://orcid.org/0000-0002-4380-5402

\section{REFERENCES}

1 Camacho-Gonzalez A, Spearman PW, Stoll BJ, et al. Neonatal infectious diseases: evaluation of neonatal sepsis. Pediatr Clin North Am 2013;60:367-89. 
2 Wynn JL, Polin RA. Progress in the management of neonatal sepsis: the importance of a consensus definition. Pediatr Res 2018;83:13-15.

3 Schelonka RL, Chai MK, Yoder BA, et al. Volume of blood required to detect common neonatal pathogens. J Pediatr 1996;129:275-8.

4 Shane AL, Sánchez PJ, Stoll BJ. Neonatal sepsis. The Lancet 2017:390:1770-80.

5 Stocker M, van Herk W, el Helou S, et al. Procalcitonin-guided decision making for duration of antibiotic therapy in neonates with suspected early-onset sepsis: a multicentre, randomised controlled trial (NeoPIns). The Lancet 2017;390:871-81.

6 Faria MMP, Conly JM, Surette MG. The development and application of a molecular community profiling strategy to identify polymicrobial bacterial DNA in the whole blood of septic patients. BMC Microbiol 2015;15:1-16.

7 Grumaz S, Stevens P, Grumaz C, et al. Next-Generation sequencing diagnostics of bacteremia in septic patients. Genome Med 2016;8:1-13

8 Brenner T, Decker SO, Grumaz S, et al. Next-Generation sequencing diagnostics of bacteremia in sepsis (next GeneSiS-Trial): study protocol of a prospective, observational, noninterventional, multicenter, clinical trial. Medicine 2018;97:e9868.

9 Grumaz S, Grumaz C, Vainshtein Y, et al. Enhanced performance of next-generation sequencing diagnostics compared with standard of care microbiological diagnostics in patients suffering from septic shock. Crit Care Med 2019;47:e394-402.

10 Gosiewski T, Ludwig-Galezowska AH, Huminska K, et al. Comprehensive detection and identification of bacterial DNA in the blood of patients with sepsis and healthy volunteers using nextgeneration sequencing method - the observation of DNAemia. Eur $J$ Clin Microbiol Infect Dis 2017;36:329-36.

11 Dark P, Blackwood B, Gates S, et al. Accuracy of LightCycler(囚) SeptiFast for the detection and identification of pathogens in the blood of patients with suspected sepsis: a systematic review and meta-analysis. Intensive Care Med 2015;41:21-33.

12 Pammi M, Flores A, Versalovic J, et al. Molecular assays for the diagnosis of sepsis in neonates. Cochrane Database Syst Rev 2017;2:CD011926.

13 Soares AER. Hybridization capture of ancient DNA using RNA baits. Methods Mol Biol 2019;1963:121-8.

14 Sharma D, Farahbakhsh N, Shastri S, et al. Biomarkers for diagnosis of neonatal sepsis: a literature review. J Matern Fetal Neonatal Med 2018;31:1646-59.

15 Brown JVE, Meader N, Wright K, et al. Assessment of C-reactive protein diagnostic test accuracy for late-onset infection in newborn infants: a systematic review and meta-analysis. JAMA Pediatr 2020 doi:10.1001/jamapediatrics.2019.5669. [Epub ahead of print: 03 Feb 2020].

16 Gögenur M, Burcharth J, Gögenur I. The role of total cell-free DNA in predicting outcomes among trauma patients in the intensive care unit: a systematic review. Crit Care 2017;21:14.

17 Volckmar A-L, Sültmann H, Riediger A, et al. A field guide for cancer diagnostics using cell-free DNA: from principles to practice and clinical applications. Genes Chromosomes Cancer 2018;57:123-39.
18 Dwivedi DJ, Toltl LJ, Swystun LL, et al. Prognostic utility and characterization of cell-free DNA in patients with severe sepsis. Crit Care 2012;16:R151.

19 Clementi A, Virzì GM, Brocca A, et al. The role of cell-free plasma DNA in critically ill patients with sepsis. Blood Purif 2016;41:34-40.

20 Liaw PC, Fox-Robichaud AE, Liaw K-L, et al. Mortality risk profiles for sepsis: a novel longitudinal and multivariable approach. Crit Care Explor 2019;1:e0032.

21 Nguyen DN, Stensballe A, Lai JC, et al. Elevated levels of circulating cell-free DNA and neutrophil proteins are associated with neonatal sepsis and necrotizing enterocolitis in immature mice, pigs and infants. Innate Immun 2017;23:524-36.

22 Kylat RI, Ohlsson A. Recombinant human activated protein C for severe sepsis in neonates. Cochrane Database Syst Rev 2006;18:CD005385.

23 El Beshlawy A, Alaraby I, Abou Hussein H, et al. Study of protein C, protein S, and antithrombin III in newborns with sepsis. Pediatr Crit Care Med 2010;11:52-9

24 Veldman A, Nold MF. Protein C and activated protein C in neonates with sepsis. Pediatr Infect Dis J 2008;27:672.

25 Thabane L, Ma J, Chu R, et al. A tutorial on pilot studies: the what, why and how. BMC Med Res Methodol 2010;10:1.

26 Geffers C, Baerwolff S, Schwab F, et al. Incidence of healthcareassociated infections in high-risk neonates: results from the German surveillance system for very-low-birthweight infants. J Hosp Infect 2008;68:214-21.

27 Tröger B, Härtel C, Buer J, et al. Clinical Relevance of Pathogens Detected by Multiplex PCR in Blood of Very-Low-Birth Weight Infants with Suspected Sepsis - Multicentre Study of the German Neonatal Network. PLoS One 2016;11:e0159821.

28 Harris PA, Taylor R, Thielke R, et al. Research electronic data capture (REDCap)--a metadata-driven methodology and workflow process for providing translational research informatics support. J Biomed Inform 2009;42:377-81.

29 Dabney J, Meyer M, Length MM. Length and GC-biases during sequencing library amplification: a comparison of various polymerase-buffer systems with ancient and modern DNA sequencing libraries. Biotechniques 2012;52:87-94.

30 Guitor AK, Raphenya AR, Klunk J, et al. Capturing the resistome: a targeted capture method to reveal antibiotic resistance determinants in metagenomes. Antimicrob Agents Chemother 2019;64:e01324-19.

31 Soares AER, Novak BJ, Haile J, et al. Complete mitochondrial genomes of living and extinct pigeons revise the timing of the columbiform radiation. BMC Evol Biol 2016;16:230.

32 Bos KI, Schuenemann VJ, Golding GB, et al. A draft genome of Yersinia pestis from victims of the black death. Nature 2011;478:506-10.

$33 \mathrm{Li} \mathrm{H}$, Durbin R. Fast and accurate short read alignment with Burrows-Wheeler transform. Bioinformatics 2009;25:1754-60.

34 Rhodes A, Evans LE, Alhazzani W, et al. Surviving sepsis campaign: international guidelines for management of sepsis and septic shock: 2016. Intensive Care Med 2017;43:304-77. 